\title{
A Survey of Pedagogical Content Knowledge (PCK): Teachers' Views on Reflection
}

\author{
Ruifeng Lyu,Jie Chen* \\ School of Foreign Studies, Guangdong University of Finance and Economics, Guangzhou, Guangdong, China \\ *Corresponding Author.
}

\begin{abstract}
This research aimed to investigate the views on reflection (one aspect of PCK) of six Chinese in-service teachers teaching College English at two universities in the south of China by using a qualitative multiple case study approach. In order to understand the characteristics of the participant teachers' views on reflection so as to make suggestions for in-service College English teacher education and development in mainland China, three rounds of data collection (pre-, in-, and post-class teaching observation) were conducted and the College English classroom teaching content analysis approach was applied in the data analysis across the cases. The data revealed that the participant teachers generally had a high level of skill in technical reflection but at times were unskilled at reflection-in-action. This case study offers an exemplar for teachers to reflect on their own teaching. It also can guide teacher educators, educational administrators, and policy makers to support teachers' self-reflection and thus improve student learning.
\end{abstract}

Keywords: PCK, teachers' views on reflection, reflection focus

\section{Introduction}

Definition: Pedagogical content knowledge (PCK) is teachers' personal understanding of how to facilitate students' mastery of specific subject matter knowledge and their enactment of this understanding by employing various kinds of instructional strategies, representations, and assessments within the local, cultural, and social education environment ${ }^{[1]}$. PCK encompasses teachers' views on knowledge ${ }^{[2]}$, language, learning, teaching ${ }^{[3]}$, and reflection.

The above interpretation of PCK originated from scholar's re-understanding of classroom teaching ${ }^{[4-10]}$. PCK is no longer regarded as a body of knowledge that can be taught; rather, it is treated as a kind of individual cognition ${ }^{[2]}$. Accordingly, education scholars, including those in the foreign language field, must start considering what teaching is and what teaching knowledge is.

When we realize that teaching is not an activity that can be imitated but encompasses teachers' personal decision-making in a complex and variable classroom environment, it becomes evident that the knowledge needed for classroom teaching is not simply the theories, principles, approaches, and techniques that can be imparted during teacher training, but the teacher's individual cognition and interpretation of teaching and learning.

Teachers' self-reflection on their own teaching is an important part of this cognition. Thus, in the current empirical study, I aimed to investigate and re-conceptualize university teachers' pedagogical content knowledge in order to understand teachers as reflective practitioners ${ }^{[11]}$. To guide the overall structure of the present study, I formulated the following general question: What are the characteristics of Chinese in-service College English teachers' pedagogical content knowledge in terms of their views on reflection?

National context: Importance of English in the People's Republic of China (PRC): Progress in China requires a reform in English language education. English education is of great concern to the education authorities ${ }^{[12]}$. English is now a major foreign language taught in schools in China ${ }^{[12]}$. University students' English language ability can be

ISSN: 0010-8189

(C) CONVERTER 2021

www.converter-magazine.info 
reflected in their scores on the College English Test (CET), which is a national standardEnglish language test for all college non-English majors in China ${ }^{[12]}$. Therefore, the teaching and learning quality of College English, which is a compulsory course for all non-English majors in tertiary education in China ${ }^{[2]}$, is critical to meeting the needs of China's development.

College English in China: Based on the College English Curriculum Requirements (2007) ${ }^{[13]}$, the most updated version of the College English curriculum used in mainland China following national education reform, College English courses have undergone various changes from previous curricula. The College English curriculum requirements are a product of modern College English innovation.

Teaching and learning objectives of College English in China (2007) ${ }^{[13]}$ : The aim of the College English course is to improve students' ability to use English in a well-rounded way, particularly in terms of their listening and speaking proficiencies, which are usually ignored in English teaching and learning in secondary schools.

Teaching requirements of College English in China (2007) ${ }^{[13]}$ : Non-English majors are required to achieve one of the three levels of requirements after studying College English. Universities set their own goals in consideration of their specific situations, make every effort to create good conditions, and encourage students who have a relatively higher English language proficiency and stronger English learning capability to achieve the higher requirements.

Teaching models of College English in China: As stated in the College English Curriculum Requirements (2007) ${ }^{[13]}$, as an essential part of tertiary education, College English is a compulsory course for undergraduates. Under the influence of related theories of language teaching and learning at home and abroad, such as the well-known communicative language teaching and learning approach, College English has as its main components knowledge of and practical skills in the English language, learning strategies, and intercultural communication.

The challenges confronting College English teachers in China: The curriculum, which emphasizes an "integrated approach," is changing what College English teachers have known about EFL teaching and learning and what they have been doing in the classroom; it is affecting their stance towards students and themselves and is leading to new criteria for "a good English class."

Research significance: If teachers, teacher educators, and teacher trainers could more deeply understand the teacher knowledge base, in particular the factors related to PCK such as "pedagogical reasoning skills and decision making" [7], students' learning effectiveness could be improved ${ }^{[14]}$. In this research, I investigated in-service Chinese College English teachers. However, many of the arguments, analyses, summaries, and conclusions in this study might also be applicable to other groups. These include not only in-service teachers but also trainee teachers because the first-hand teaching experiences of in-service teachers are of great help in fully preparing trainee teachers for their future careers. Not only university English teachers but also teachers of other subjects and those at other levels of education, such as high school or primary school, could benefit from this study.

\section{Literature Review}

Teacher knowledge: Recently, scholars have argued that teaching is a profession, and this profession produces its own specialized knowledge essential to practice; meanwhile, the teacher is considered to have a knowledge base that is developed through his or her teaching practice. This knowledge base consists of the skills teachers need to master for teaching, an important issue in teacher education ${ }^{[15]}$.

It was assumed for a long period of time that the knowledge teachers needed for teaching was knowledge of their subject matter, but what characterizes a qualified teacher in practice is not just subject matter knowledge. This is why there are always complaints from students about the inefficiency of professors in their classroom teaching ${ }^{[16]}$.

ISSN: 0010-8189

(c) CONVERTER 2021

www.converter-magazine.info 
Pedagogical content knowledge was first introduced by Shulman to represent a specific type of teacher knowledge that distinguishes a teacher of a subject from an expert on the subject ${ }^{[15]}$.

It is important to be clear that teacher knowledge is a general technical term that covers a great variety of teacher cognition, due to the fact that different components of knowledge are intertwined in teachers' minds. This is relevant to teacher knowledge research where the main attention is on the complexity of cognition, the ways it develops, and the way it interacts with teachers' behaviors in classrooms. Consequently, it makes sense to investigate teachers' knowledge.

Many terms related to teacher knowledge have been applied in journal articles, each with a focus on a different aspect of teachers' knowledge ${ }^{[17]}$, for instance, personal knowledge ${ }^{[18]}$, situated knowledge ${ }^{[19]}$, professional craft knowledge ${ }^{[20]}$, action-oriented knowledge ${ }^{[21]}$, and tacit knowledge ${ }^{[22]}$. From all these, a general picture can be drawn of how teacher knowledge has been studied in the past ${ }^{[23]}$. Teacher knowledge in this study referred to all knowledge influencing a teacher's teaching practice ${ }^{[23]}$.

A lot of educational research has been aimed at developing a knowledge base for teaching so as to put forward some suggestions for teacher education and development ${ }^{[24]}$. As a well-known theoretical framework, Shulman's ${ }^{[25]}$ comprehensive explanation of the knowledge base for teaching, in which he defined a set of general areas of teacher knowledge for teaching, including PCK, has been widely applied in educational projects. PCK has become central to the teacher knowledge base because the research on PCK indicates that it is closely related to a teacher's classroom teaching practice. PCK represents the teachers' professional knowledge and is frequently referred to in journal articles ${ }^{[15]}$.

Teachers' views on reflection:Reflection is emphasized in a teacher's PCK development in Shulman's model. Teachers' reflection on their teaching practice helps them become aware of their own knowledge ${ }^{[26]}$. Therefore, teacher education should emphasize teachers' self-reflection on their teaching practice in order to further their PCK development.

Teachers are the most important factor affecting teaching and learning in the foreign language classroom, so teachers must understand the principles of their own development. Teachers' professional development is an extremely complicated cognition process. Constructivism is the learning theory fundamental to teacher learning and cognition. Foreign language teachers must construct their understanding of foreign language teaching and learning based on their individual teaching practice and social exchanges. Reflective practice, as it was introduced by [27], is not just a form of thought but is also integrated into teachers' practical activities. This is an approach that will greatly assist teachers' development, as it can contribute to the development of teachers' personal knowledge of teaching.

Teachers may have to try new ideas in their classroom teaching practice repeatedly based on their existing knowledge and experience. In addition, they have to confirm the varieties of personal knowledge related to their subject (for example, foreign language teaching) and then examine, reflect upon, and revise their incorrect ideas to gradually establish their new understanding of teaching. It is this new understanding originating from practice that helps teachers' personal knowledge to improve and develop constantly. In other words, it is the individual sustainable development obtained from teaching practice, exchanges, and reflection that directs teachers' classroom teaching decisions and students' learning. Three types of teacher reflection have been outlined by scholars as follows.

Experience thinking: When a teacher is delving into vague and abstract issues, typically his or her consideration of a topic is carried out based on specific experiences. This kind of consideration is described as experience thinking. 
Experience thinking is valuable because teachers tend to address classroom teaching issues in accordance with the methods, approaches, and skills that have been established by experts, scholars, and supervisors, rather than dealing with these issues using their individual experience or intuition. If a teacher is constrained by this approach to reflection in the long term, it is possible for him or her blindly to follow established theories and accordingly ignore his or her personal perceptions. In this case, it will be difficult for the teacher to achieve any kind of breakthrough in using more flexible teaching approaches and skills. It is also very difficult for teachers to improve their teaching knowledge if they pay little attention to the features of their own teaching or do not attach any importance to their exchanges with students in the classroom.

Technical reflection: Teacher's technical reflection refers to their technical analysis of teaching skills ${ }^{[28]}$. When conducting this kind of reflection, the teacher mainly focuses on teaching elements that have a direct impact on teaching performance. Some research has indicated that technical reflection enables the teacher to apply research results at a technical level and translate education theories into teaching practice ${ }^{[29]}$. In this type of reflection, teachers typically conduct rational analyses and discussions of teaching skills. Like experience thinking, technical reflection allows teachers to go beyond blindly following established theories. However, it also is a deeper form of reflection than experience thinking, in that it helps teachers to examine their own practices critically.

Therefore, teachers may utilize their own regular teaching experience as well as theory in this type of reflection. In addition, taking advantage of other people's practical experience is also beneficial. However, simple technical reflection may lead teachers to believe falsely that they are able to control all technical aspects of the entire teaching process, which can produce some harmful side effects. Firstly, teachers' individual views and the teaching influences caused by the particular teaching environment may be ignored, and secondly, teachers may neglect coordination with their classroom environment, which absolutely would negatively affect the learning and development of both the teacher and students.

Reflection-in-action ${ }^{[27]}$ : When a teacher makes a decision in the classroom, accurate and complete individual comprehensive teaching knowledge is demonstrated by his or her intuition, including knowledge, experience, emotions, and thoughts. Additionally, the decision probably has an impact on students' learning at multiple levels. Reflection-in-action is a deep type of reflection takes these factors into account and allows teachers to avoid the constraints of technical reflection.

In the changing classroom, teachers have to define and coordinate a variety of indefinite, unstable, and complicated classroom environmental factors, striving to enhance the joint learning and development of both themselves and their students. In addition, the teacher is required to reference various kinds of relevant knowledge and experience to enhance his or her teaching knowledge constantly. Reflection-in-action is reflection that occurs during classroom teaching and allows the teacher to make ongoing adjustments. It encompasses an overall focus on the whole teaching process, not a mere emphasis on technical issues. Reflection-in-action features decision-making that directly affects students' learning quality and teacher's professional development, including the blending of the teacher's professional attitudes and competence.

\section{Methodology}

Data analysis: The purpose of this study was to analyze teachers' College English classroom teaching to understand the teachers' views on reflection, an aspect of their PCK. It was part of a larger study that also examined four other aspects of the teachers' PCK: their views on knowledge, language, learning, and teaching.

The process of analyzing the specific content of teaching ${ }^{[30]}$ can result in a clearer interpretation of the actual relationship between teaching and learning. Thus, content-oriented analysis of teaching ${ }^{[30]}$ was employed in this 
research. This type of analysis is intended to analyze the relationships among different factors in teaching: the students and teacher; the classroom environment; the content taught; and the students' psychological situations.

The data were analyzed using the constant comparative approach ${ }^{[31]}$, later known as the grounded theory method ${ }^{[32]}$. Different participant teachers were compared in terms of their views on reflection by examining examples using within-case and cross-case analysis ${ }^{[33]}$ because, in a multiple case study, "the researchers have an obligation to provide interpretation across the cases" ${ }^{[34]}$. In this way, multiple sources of evidence can be analyzed and a chain of evidence constructed ${ }^{[35]}$. In this research, the chain described the general features of the teachers' views on reflection.

The data in this research were qualitative: they included interviews, classroom teaching observation transcriptions, stimulated recall transcriptions, extensive field notes with lesson summaries, lesson plans with rationales, self-reflection teaching reports, textbooks, and curriculum requirements. Once data were collected, it was essential to organize the information into three categories: pre-, in-, and post-classroom observation. Each data-set was read several times to pinpoint the most distinguishing features of each participant teacher and was then analyzed manually within the analytical framework. The framework used to analyze the participant teachers' views on reflection was organized based on the various reflection focuses evident in the teachers' data ${ }^{[13]}$. Under each analyzed category, open coding was employed and sub-headings emerged.

\section{The analysis of teachers' reflection focuses}

Experience thinking: When teachers only talked about what they did in their classroom teaching, about their spoken language, or about their specific classroom teaching methods, which were all easily visible aspects of their classroom teaching, this type of reflection was categorized as experience thinking.

Technical reflection: If, in addition to reflecting on their teaching behaviors, a teacher was able to address other aspects of their classroom teaching such as its problems, objectives, or features (aspects were more in-depth than experience thinking but still stressed the importance of the teacher's technical skills in classroom teaching), this type of reflection was categorized as technical reflection.

Reflection-in-action: Moreover, if a teacher focused on issues in their classroom teaching such as the details of classroom decision-making, students' learning effects and feelings, or the relationship between teaching and learning, which are quite holistic reflections, this type of reflection was categorized as reflection-in-action.

Sample: Two universities located in the south of China were selected in this study as research sites. One was Finance University (a pseudonym) in Guangzhou, the capital city of the province of Guangdong, a relatively more developed area in the mainland of China. The other university was Teachers University (also a pseudonym) in Haikou, the capital city of the province of Hainan, a relatively less-developed region. I chose this university, which has a teacher education orientation, to contrast with Finance University, which has a major business orientation. I sent invitation letters to twenty teachers (ten from each school) on the recommendation of the heads of the School of Foreign Languages at each university. Ten teachers replied to me with their willingness to be my participants. In consideration of the sample size and the teachers' diversity, six of them were successfully selected. Table 1 shows the particulars of the participants in this study.

Table 1Participant Teachers' Particulars

\begin{tabular}{|l|l|l|l|l|l|l|}
\hline \multirow{2}{*}{} & \multicolumn{5}{|l}{ Finance University (FU) } & Teachers University (TU) \\
\cline { 2 - 7 } & Ding (FU1) & Deng (FU2) & Yang (FU3) & Wei (TU1) & Liu (TU2) & Xie (TU3) \\
\hline Gender & F & F & F & F & M & F \\
\hline DOB & 1980 & 1980 & 1977 & 1977 & 1979 & 1973 \\
\hline Position & Instructor & Instructor & Instructor & Instructor & Associate instructor & Associate Prof. \\
\hline Experience & 9 years & 8 years & 11 years & 11 years & 11 years & 15 years \\
\hline
\end{tabular}

ISSN: 0010-8189

(C) CONVERTER 2021

www.converter-magazine.info 
Volume 2021, No. 5

\begin{tabular}{|l|l|l|l|l|l|l|}
\hline Interest & $\begin{array}{l}\text { Teaching \& } \\
\text { literature }\end{array}$ & Literature & Literature & Linguistics & TEFLM \& ETE & Translation \\
\hline Degree & MA & MA & MA & MA & BA & Ph.D. \\
\hline Major & Literature & Literature & ELL & Literature & TEFLM & Translation \\
\hline Score/Percentage & 94.14 & 91.904 & 92.162 & 92.744 & 95.02 & 91.838 \\
\hline University/Level & SYSU/Key & SCNU/Key & SCNU/Key & GXNU/Other & HNNU/Other & JNU/Key \\
\hline Award & Provincial & No & No & Provincial & No & No \\
\hline
\end{tabular}

Notes:

a. TEFLM \& ETE= TEFL methodology and English teacher education

b. Position= professional position title

c. Experience $=$ years of teaching the College English course

d. Interest= academic and teaching research interests/directions/areas

e. Degree $=$ the highest degree obtained

f. Major= major of the highest degree

g. Score $=$ the latest score by students on classroom teaching at the end of term

h. University $=$ the university where the highest degree was awarded

i. Award= award for College English teaching

j. $\quad E L L=$ English language and literature

k. SCNU= South China Normal University

1. GXNU= Guangxi Normal University

m. HNNU= Hainan Normal University

n. JNU= Jinan University

o. SYSU $=$ Sun Yat-sen University

The data collection was divided into three phases: pre-classroom observation, in-classroom observation, and post-classroom observation. After obtaining informed consent from the participants, I completed an initial interview with each teacher in Chinese, the mother tongue for both the interviewer and the interviewees. Each interview lasted from one to two hours, and the guiding initial interview questions were sent to the interviewees beforehand.

These interviews were audio-taped and transcribed. I also asked each teacher to supply me with a lesson plan for their lesson that I would observe during the in-classroom observation phase, as well as the textbook and curriculum that they would use. In China, standardized national textbooks and curriculum are used for College English, but teachers and schools have the right to modify them. The documents the teachers supplied to me allowed me to understand whether they were following the standard textbook and curriculum or had adapted them in some way.

During the in-classroom observation phase, I observed each teacher once in a forty-five-minute College English classroom teaching session. The observed classes were audio-taped and videotaped. The audio-taped classroom observation data was mainly used for transcription while the videotaped data was mainly used for investigating the teacher's body language and gestures.

I also kept extensive field notes during the observation. Finally, during the post-classroom observation, each teacher completed a self-reflection teaching report on the lesson I had observed. Then, they completed a stimulated recall activity with me. We viewed the videotape of their lesson together, and I paused the replay to ask clarifying questions about their cognition during the lesson. In order to prepare for this activity, I previewed the videotapes alone and marked places where I wanted to ask clarifying questions. Table 2 illustrates the entire data collection procedure with specific phases and methods.

ISSN: 0010-8189

C CONVERTER 2021

www.converter-magazine.info 
Table 2Sources of Data

\begin{tabular}{|c|c|c|c|}
\hline & Phases & Methods & Data \\
\hline \multirow{8}{*}{$\begin{array}{l}\text { DataCollecti } \\
\text { on }\end{array}$} & \multirow{4}{*}{$\begin{array}{l}\text { Pre-ClassroomO } \\
\text { bservation }\end{array}$} & Interview (Written or spoken) & Personal document: Interview transcription (If spoken) \\
\hline & & $\begin{array}{l}\text { Lesson plan with rationale } \\
\text { (Written or spoken) }\end{array}$ & $\begin{array}{l}\text { Personal document: Lesson plan, Personal document: Rationale } \\
\text { transcription (If spoken) }\end{array}$ \\
\hline & & Textbook & Official document: Textbook \\
\hline & & Curriculum requirements & Official document: Curriculum requirements \\
\hline & \multirow{2}{*}{$\begin{array}{l}\text { In-Classroom } \\
\text { Observation }\end{array}$} & \multirow[b]{2}{*}{ Video recordingAudio recording } & Personal document: Field notes \\
\hline & & & Personal document: Classroom teaching transcription \\
\hline & \multirow{2}{*}{$\begin{array}{l}\text { Post-Classroom } \\
\text { Observation }\end{array}$} & $\begin{array}{l}\text { Self-reflection teaching report } \\
\text { (Written or spoken) }\end{array}$ & Personal document: Self-evaluation transcription (If spoken) \\
\hline & & Stimulated recall & Personal document: Conversation transcription \\
\hline
\end{tabular}

\section{Data Analysis: The Analysis of Teachers' Reflection Focuses}

Experience thinking: Most of the teachers in this study showed evidence of experience thinking in their self-reflection. Experience thinking is the least complex level of self-reflection teachers can experience. The following analysis of teachers Wei, Deng, Yang, and Liu's stimulated recall show how some of their reflections on their own classroom teaching practices were based on their past teaching experiences. For example, these teachers all addressed the importance of lesson objectives in their reflection reports:

Reflection report extract (Teacher Wei): This lesson had clear objectives based on my first-hand classroom teaching experience.

Reflection report extract (Teacher Deng): This lesson had reasonable stages with clear objectives since this was my usual practice.

Reflection report extract (Teacher Yang): It was necessary to explain the teaching objectives of the lesson to my students.

Teachers Wei and Deng seemed to be clear about the objectives that they wanted to achieve at each stage of their lessons: what to teach and how to teach it. The lesson objectives were based on both the curriculum requirements and their accumulated experience in daily teaching. I was told by the participants that College English teachers at Finance University had the habit of introducing their lesson objectives to the students before the new lesson was formally started, but few teachers could clearly give a rationale for why they did this. (Very often lesson objectives, which summarize a lesson from a theoretical point of view, are only intended for the teachers' own use, and therefore, students do not have to know them. In fact, the vocabulary used in lesson objectives may confuse students.) Instead of lesson objectives, teacher Liu attached importance to the whole design of a lesson.

Reflection report extract (Teacher Liu): This lesson plan was designed well.

It may be true that, from the perspective of a teacher's pre-class planning, teacher Liu's lesson plan was logical and cohesive. It trained the students in reading strategies (skimming and scanning) by doing classroom pedagogical tasks in order to facilitate their critical understanding of the lesson topic. However, teacher Liu seemed not to reflect on how well the lesson plan matched the students' real needs during classroom learning or how he could adjust the plan during class based on those needs. Teacher Liu appeared not to consider the lesson from the students' perspectives. Besides the lesson design, teacher Liu also thought highly of the time control in his lesson.

Reflection report extract (Teacher Liu): The timing of this lesson was well controlled.

In this lesson, teacher Liu allocated proper amounts of time to various students' classroom activities that were linked to different objectives in the lesson. However, he placed more stress on whether he could control the classroom time

ISSN: 0010-8189

(C) CONVERTER 2021

www.converter-magazine.info 
as planned than on how much time the students needed to complete each classroom task. While classroom time control plays a role in the quality of classroom teaching, teacher Liu seemed to ignore the idea that all the time spent in classroom teaching that facilitates students' learning is worthwhile.

The above discussion about teachers' experience thinking is all from a macro-perspective (lesson objectives, lesson design, and time control); below, teacher Yang's experience thinking reflects a micro-perspective: the method she adopted to reduce the difficulty of listening comprehension materials.

Interview extract (Teacher Yang): My way to reduce the difficulty of the listening materials was to let the students listen again after class.

Repeated listening is indeed a way to lower the difficulty level of listening materials but it is difficult for a teacher to guarantee that students will listen after class. Other ways to make listening comprehension easier include adjusting the listening materials to the students' English language proficiency, making use of other classroom organization forms like collaborative learning, or doing more preparation for students' listening with regard to vocabulary, topic discussion, background information, and the context of the dialogues. However, Teacher Yang's reflection remained at the experience thinking level, which may have limited her consideration of other options. Another example of teacher Yang's experience thinking showed that she was open to analyzing problems with her classroom teaching with others' help, but she found it difficult to pinpoint these problems on her own.

Interview extract (Teacher Yang): I am not able to determine any problems with my classroom teaching though I admit there was room for improvement.

Though teacher Yang tried to list some possible problems with her classroom teaching, she was honest she was honest about her struggle to do so in her classroom teaching self-reflection. She followed up this point by mentioning that she would like to exchange ideas and experiences with other teachers involved in this study. From these statements, we can see this teacher's willingness to deepen her teaching reflection strategies by communicating with fellow teachers but also the challenges she encountered in moving beyond experience thinking.

Technical reflection: The teachers' reflections about their own classroom teaching practices outlined above were mainly dependent on their experiences of their daily work. Experience thinking takes place at a basic level and is a good start for teachers' reflections on classroom teaching practice. However, the data analysis in this session suggested that the participants' reflections were not only based on their general experiences. This means the teachers were able to reflect more specifically and in more depth. The following results showed the teachers' potential in their technical reflections. Technical reflection is a teacher's ability to reflect on the specific skills, techniques, or methods he or she applied in classroom teaching. In the following reflection example, teachers Deng and Liu wanted to employ more ways to lead into the topic of a new lesson to pique their students' interest.

Reflection report extract (Teacher Deng): More teaching forms should be adopted for leading into the topic of the unit such as using film clips in order to stimulate students' interest.

Interview extract (Teacher Liu): I should find a better way to lead in because the video did not help to warm students up.

While both teachers were interested in leading their students into their lessons more effectively, their reliance on technical reflection may have limited their understanding of their students' needs in this matter. Teacher Liu's video was actually about the difficulties a man experienced while learning English language pronunciation, while the topic of the reading passage was how the English language has become the first truly global language. Teacher Liu rightly stressed the importance of "leading in" her College English teaching, but the lead-in of a lesson need not be long or

ISSN: 0010-8189

(C) CONVERTER 2021

www.converter-magazine.info 
complicated; a brief and simple lead-in may work as well. Other points overlooked in this reflection were that lesson lead-ins should be used not only to stimulate students' interest but also to facilitate students' English language learning process, and that students' interest in English may not even be a crucial consideration in College English learning. Many of teacher Liu's students, who were not English majors, probably had no intrinsic interest in English, and it might be too much to expect that a teacher could greatly interest such students in College English during limited weekly periods of time. Teacher Yang reflected on her use of another technique, games, to stimulate students' interest in her classroom teaching.

Interview extract (Teacher Yang): I stressed the students' motivation to learn in class; thus, I employed games.

College English is just a general course in China, and the students in this lesson were not English or language majors. Students' motivation to learn really plays an important role in ensuring participation in College English classes, but teacher Yang's focus on technical reflection may have limited her exploration of other ways to increase the students' learning motivation besides games, such as the coherence, connections, and forms of the classroom pedagogical tasks. In another example, teacher Yang's technical reflection also highlighted her method of facilitating her students' listening comprehension by presenting the expressions used in the lesson with PowerPoint.

Reflection report extract (Teacher Yang): The expressions presented on the PowerPoint and explained for the students before their listening comprehension exercises could facilitate the students' listening ability.

Again, teacher Yang's focus on technical reflection may have limited her exploration of the most effective way to attain this learning objective. On the one hand, college students already have a certain amount of English vocabulary, so another way to train the students' ability is to guess vocabulary meanings in the listening comprehension context based on their current vocabulary. On the other hand, the expressions, which were explained without concrete context by the teacher, might have been difficult for the students to remember in a short period of time, so the students might not be able to recognize them in the listening materials quickly. One more crucial question is whether it was necessary for the teacher to explain the expressions. Did the expressions affect the students' understanding of the listening materials or their ability to do the multiple-choice questions? Reliable answers to this question might require a survey (probably designed by the teacher herself) of her students after class. The teacher had not done this at the time of her interview. This final example also represents teacher Yang's technical reflection.

Interview extract (Teacher Yang): My guidance in the model dialogue enabled the students to see the conversation from a pragmatic point of view.

Again, teacher Yang focused on her use of a specific teaching technique rather than on exploring the various ways in which her students could acquire a certain skill. It is essential for college students to understand pragmatics, and there are many ways for students to acquire this knowledge. For example, teacher Yang could have facilitated the students' discovery of the outline and principles of the dialogue by themselves.

Reflection-in-action: Reflection-in-action shows a teacher's potential to adjust his or her pre-planned lesson in the changing classroom to fulfill the needs of students. It is the most complex level of reflection among the three types of reflection addressed in the literature review. The data showed that teachers Wei, Ding, and Deng were able to reflect in action. The following examples of teachers Wei and Ding, who took students' output seriously, showed their reflection-in-action.

Interview extract (Teacher Wei): Students could comprehensively and deeply discuss the problems that face the old in modern society, with constructive suggestions, by using English with the teacher's purposeful support before class.

ISSN: 0010-8189

(C) CONVERTER 2021

www.converter-magazine.info 
Interview extract (Teacher Ding): The students were able to make efficient output independently by employing most of the expressions learnt in class.

It may be wise to evaluate the quality of College English classroom teaching using students' language output, for example, whether students can talk about an issue critically in depth from different angles by collaborating with peers in the target language. The two examples above showed that these two teachers were able to reflect on students' comprehensive use of the English language during their output, and these thus are examples of reflection-in-action.

However, teacher Ding's reflection could have been deeper if she had paid more attention to her teaching context. She regarded her lesson as effective as long as the students could use in their output the vocabulary items and expressions that she had introduced in class. At the university level, College English students may have different vocabulary sizes due to their various majors. Therefore, a possible way for teachers to deal with vocabulary in College English classes may be to let students search for the vocabulary they need on their own by making use of learning resources such as dictionaries, with the teacher's assistance when necessary in terms of pronunciation, spelling, and usage. Besides students' output, teachers Wei, Ding, and Deng all paid attention to the classroom teaching atmosphere, which also could be regarded as evidence of their reflection-in-action.

Reflection report extract (Teacher Wei): The students' learning effect was favorable in this lesson because they participated in the classroom activities warmly with keen interest and passion so that the classroom atmosphere was enlivened.

Interview extract (Teacher Ding): The classroom atmosphere was active because the students warmly participated in the classroom activities.

Reflection report extract (Teacher Deng): The students warmly took part in the classroom activities so that the classroom atmosphere was active.

It is common for a teacher to evaluate the quality of classroom teaching based on both the classroom atmosphere and students' positive reactions to classroom activities, although these considerations should not outweigh all other aspects of teaching that can be affected by teachers' PCK. At least these teachers cared about the classroom teaching atmosphere and were able to create a favorable environment for students' classroom learning through their reflection-in-action. In addition, teacher Ding also showed her use of reflection-in-action when she underlined the students' understanding of her instructions.

Interview extract (Teacher Ding): The students were able to understand my instructions.

Teachers' instructions are of great importance in foreign language teaching and learning because how well students complete the classroom activities is partly based on whether they are clear about the teacher's instructions, including what to do, how to do it, and the time limit. The students in teacher Ding's class were able to produce high-quality output without misunderstanding the instructions from the teacher. That is to say, the teacher monitored her classroom teaching to ensure that the students were able to follow her instructions.

Contrary to the above examples, which suggest teachers' ability to reflect in action, the following analysis suggests that, in some cases in their classroom teaching, teachers Wei, Xie, Liu, and Ding did not reflect in action; they all agreed that some parts of their lesson plans were too time-consuming, but they were unable to reflect on this fact and make adjustments during their lessons.

Reflection report extract (Teacher Wei): Students' in-class presentations were time-consuming. Reflection report extract (Teacher Xie): Cancel unnecessary content in the lead-in part of the lesson because it was time-consuming.

ISSN: 0010-8189

(C) CONVERTER 2021

www.converter-magazine.info 
Reflection report extract (Teacher Liu): The post-reading discussion should be done in the next class because class time was limited.

Interview extract (Teacher Ding): In-class time should be allocated more to students' activities in order to make the whole class efficient and cohesive, rather than to my own inputting of vocabulary. It would be better to let the students collect relevant vocabulary in advance before class instead of my introducing it in class, which is time-consuming.

It might have been good for teacher Xie to shorten her explanation of the song lyrics that functioned as the lead-in to the lesson topic; so long as the students had a general understanding of the song, the objective of playing it would be achieved. There was possibly no need for the teacher to explain in detail the lyrics of the song, sentence by sentence. In addition, canceling the long explanation of the song lyrics would be recommended not just because it was time-consuming but also because this part of the lesson strayed far from the lesson objectives. (The lyrics did not contain the vocabulary the students needed to learn in the lesson.) Teacher Xie was able to reflect on this problem in her teaching after the lesson was finished, but she struggled to reflect on it during class time.

In addition, the point teacher Ding made was convincing because, in College English classes, which emphasize students' integrated use of English, students should be offered as many opportunities as possible for language output. However, all the time spent in class practicing students' comprehensive use of the English language is worthwhile. Moreover, teacher Ding showed the students vocabulary on PowerPoint slides in class without context, so the vocabulary might be difficult for the students to remember in a short period of time. Though the teacher wanted to ask the students to collect relevant vocabulary before class, they might still need some context in which to do this. They could be assigned a pedagogical or real-life task with a clear purpose for which they had to collect vocabulary. Again, teacher Ding was able to reflect on these considerations after class but not in the moment.

All the teachers quoted in the extracts above focused on classroom time control, but classroom teaching should be flexible so that a teacher can adjust according to students' real needs (such as deleting something, adding to the lesson, changing the order of activities, or repeating something). This is the essence of reflection-in-action. A teacher may find it difficult to make such adjustments because they find it challenging to make decisions in the classroom. Another example from teacher Xie proved that she experienced this difficulty, and it negatively affected her reflection-in-action.

Interview extract (Teacher Xie): I felt uncertainty about whether the students knew how to grasp the main idea of a text. This was not a student-centered class because I talked too much and the students looked uninterested and tired. I should improve students' initiative in English study by using more instructive questions.

Teacher Xie was not sure about whether the students grasped the main idea of a text because she did not check students' understanding through interaction (for example, through their responses to her questions, their eye contact with her, and their speed in answering questions). In this lesson, the teacher's questions seemed fast or possibly did not grab the students' attention. In contrast, high-quality questions from teachers in the classroom may help to promote students' initiative in English learning. My in-classroom teaching observation of teacher Xie did not capture student-centered classroom teaching, and the students did not look very active throughout the lesson. Although teacher Xie realized that she talked too much in the lesson and left her students with little time to express their own ideas freely, she did not adjust her teaching during the lesson. Related to the topic of student participation, teacher Liu explained in the interview his students' reluctance in the classroom.

Interview extract (Teacher Liu): Students were reluctant to participate in the classroom activities in this lesson. From my perspective, I will firstly seek the reasons from my own side. I am shy, nervous, and unconfident. As I have been making every effort to become a rational and calm teacher instead of using a passionate or sentimental style, to some 
extent I probably represent this kind of teaching style in my classroom teaching and my way of expression, both of which can obviously demonstrate that I am not so passionate. Thus, my capability of stimulating students' initiative is not enough. The second reason possibly comes down to the point that a considerable number of students find it difficult to keep up with what I talk about in English. Thus, these students cannot be involved in the classroom teaching activities. Some students cannot even totally make themselves understood. Apart from that, some of them are too shy and scared to participate in classroom activities. This is closely associated with our traditional culture, which is not especially approving of active participation in classroom activities.

Again, this teacher was able to reflect on his teaching after the class but was not able to make adjustments in the middle of his teaching. In fact, some of the problem teacher Liu brought up, such as his character traits, were probably impossible to change in a short period of time, but it was still courageous for the teacher to search for the source of his own problems. The topic of this lesson, the history of English, should be familiar to all his students because they had been learning English for more than ten years, that is to say, to some degree English had accompanied their growing up. So, from this perspective, they should have had an interest in English history, or at least they should not hate it. In this situation, it is necessary to think about the reasons behind the students' reluctance to take part in the classroom activities. Classroom organization could affect the students' willingness to participate, and this is an aspect of teaching that could be adjusted through reflection-in-action; teacher Liu could encourage participation through collaborative learning forms like group work or classroom management techniques like numbering the students to answer questions after preparation. These efforts could help address the difficulty teacher Liu mentioned in which sometimes students do not volunteer responses owing to the classroom culture in China in which students, and especially adult students, do not put their hands up to answer the teachers' questions due to shyness, although they know the answers. The last example from teacher Deng tells us the way she dealt with classroom activity forms. Again, this example shows that teacher Deng struggled with reflection-in-action, although she could analyze problems in her teaching after the class was finished.

Interview extract (Teacher Deng): I should ask students to choose speaking activity forms by themselves in order to stimulate their initiative and overcome their shyness so that they can complete the classroom tasks as expected.

The classroom activities in this lesson were controlled more by the teacher than the students, and the students very often simply followed the teacher without much creativity or imagination. This class might become more student-centered if the students could be given the right to choose activity forms on their own. Besides, the teacher felt that the students could not complete the tasks as expected because of their shyness. Due to the classroom culture in China, shyness might be one reason for the non-completion of the classroom pedagogical tasks, but there are perhaps more persuasive reasons to explain this. For example, college students may be more stimulated and motivated if a task is more challenging and asks students to think critically by communicating in groups for a specific purpose with real identities, not simply follow the teacher and the textbook.

Teachers' views on students' lifelong learning: In the previous section, three levels of teacher reflection were discussed: experience thinking, technical reflection, and reflection-in-action. Last but not least, teachers Wei, Xie, and Liu also reflected on students' lifelong learning.

Interview extract (Teacher Wei): Students' before-class preparation for in-class presentations can help to promote their lifelong learning. Students' independent work outside of school can help to train their autonomous learning habits and ability, which may be beneficial throughout life.

Interview extract (Teacher Xie): I paid special attention to the students' development in my College English classroom teaching because I hold the view that College English, an obligatory course in Mainland China, should be able to teach students something beneficial to their lives. 
College English is only a two-year course, so these teachers cared about the future significance that College English could bring to students when they finished the course or when they entered society after graduation. This perspective caused teachers to reflect on what College English can provide to students: vocabulary, a passion for learning, or some practical skills that students can apply? The teachers' answer was the latter. Therefore, in their own College English classroom teaching, they never stopped exploring the practical skills that students could use. For example, teacher Xie shared with us her self-invented teaching methodology.

Interview extract (Teacher Xie): In recent years, I have been trying a self-invented teaching methodology, "key words teaching methodology," in my own classroom teaching of College English. This method teaches students through reading how to catch the key words in a sentence, in a paragraph, or in a passage (for example, how to grasp the main idea of a text).

Teacher Xie thought that the skill of catching key words could not only be used in the English and Chinese languages but also in many other aspects of life, for example, how to abstract useful information from others' speech, how to understand the real intentions of the person who talks with you, and how to express yourself precisely. Therefore, in the observed class, Teacher Xie said that the last part of the lesson, in which she helped the students understand the structure of an article, was the highlight of the class. (The students were expected to know the gist of the text, the main idea for each part, the topic sentence for each paragraph, and the key words for each sentence.) She said this was not only because she was good at teaching this part but also because this part contained what she felt to be the most important knowledge for her students. Similar to teacher Xie, teacher Liu also gave an example of classroom teaching that revealed his view on students' development.

Interview extract (Teacher Liu): I hold the opinion that critical thinking is essential for students' development whether in study or in their future lives, based on my own personal experiences and my observation of the experiences of other people around me.

Based on this point of view, in his own College English classroom teaching, Teacher Liu kept training students' critical thinking ability. In his observed lesson, in order to let the students think critically, he asked them to comment on an author's opinion from different perspectives with his guidance. This activity also laid the foundation for the discussion of a real-life issue in China later in the lesson. In this discussion, the students once again needed to practice independent critical thinking because they had to list the reasons for their answers. Therefore, students' development was emphasized in this teacher's College English classroom teaching.

However, teacher Liu could have extended his reflection on opportunities to learn lifelong skills. For example, in his lesson, another good opportunity to practice the students' critical thinking ability came at the beginning of the class. When the students answered the teacher's question, "Why do we need to learn English?", a question that could potentially elicit some significant answers from the students, the teacher should have made full use of the answers to compare and contrast the students' ways of thinking with the author's opinions in the text on the same issue. For example, the students could have answered from the perspective of imperial colonization, while the author's perspective of the text was that of the history of English language development. In this case, comparison and contrast could be made by the teacher for the students, which could motivate the students' reading of the text.

Teachers' environment for reflection: After several informal talks with teachers and leaders at Finance University, I learned that, in fact, it was relatively difficult for teachers in the foreign language department there to form reflection groups to improve the quality of College English language classroom teaching. There were a number of reasons for this. First of all, this university was initially centered upon finance- and economics-related majors, so the institution did not, at the time of this study, give much support to the development of language-related majors. 
Besides, even within the Department of Foreign Languages, the development of language major courses (like English and Japanese majors) took priority over general courses (like College English and French-related courses). Moreover, even within College English courses, teachers did not have the custom of observing each other's classroom teaching for self-improvement because, from the very beginning, a large number of teachers regarded their classroom teaching as private and something that they did not want others to observe, discuss, or comment on.

In addition, this university emphasized faculty academic research output (such as academic papers and projects) more than the quality of classroom teaching, which is relatively difficult to assess due to the lack of objective (as opposed to subjective) criteria. More importantly, College English teachers at this university mostly did research on English language literature, translation, and English for special purposes but not on English teaching methodology, second language acquisition, or teacher education and development. Finally, all the deans and vice deans in the foreign language development at this university seldom did research on classroom teaching. All in all, it seemed that it really would take time to encourage College English teachers to do research on classroom teaching (a type of reflection) at this university.

\section{Discussion}

The evidence in the teachers' reflection reports showed that the reflections of the teachers in this study covered everything from experience thinking to technical reflection to reflection-in-action. In terms of experience thinking, some teachers, such as teachers Ding, Deng, Yang, and Wei, considered the classroom teaching and learning atmosphere to be an important criterion when evaluating their classroom teaching. As to technical reflection, teachers highlighted the importance of specific techniques in their classroom teaching for improving the quality of students' learning; all the participant teachers addressed this point in their reflection. With regard to reflection-in-action, which seemed to be the most challenging point for the participants in this study, very often the teachers were cognizant of their problems in the course of classroom pedagogical reasoning and decision-making, but they were unable to solve these problems in the moment by adjusting their classroom teaching to fulfill students' needs; all of the teachers in this study except teacher Yang referred to this point.

It is evident that most of the teachers in this study (such as teachers Ding, Deng, Wei, Xie and Liu) relied heavily on technical reflection. These teachers stressed the application of various teaching techniques in their daily classroom teaching. However, $\mathrm{Han}^{[2]}$ mentioned that reliance on simple technical reflection may cause teachers to over-inflate their belief that they can control the technical attributes of the overall teaching process. As a consequence, they may ignore their personal understanding, as well as the impacts of a particular teaching environment on their teaching. They may also neglect teachers' and students' joint learning and development through coordination with the classroom environment, especially through students' coordination.

Han ${ }^{[2]}$ summarized that various aspects of teachers' PCK may have impacts on each other. For example, teachers' approaches to self-reflection may be affected by their views on teaching. Teachers who hold the imparting view on teaching may have difficulty reflecting deeply on their own teaching because they place more emphasis on imparting knowledge and less on the development of students' knowledge frameworks. When teaching reflection is limited to whether students acquire knowledge accurately, or is constrained merely to the technical skills of imparting knowledge, these teachers probably can easily overlook the possible impacts of classroom decision-making on students' knowledge frameworks.

\section{Conclusion and Implications}

The results of the data analysis in this study revealed the participant teachers generally had high levels of skill in technical reflection but at times were unskilled at reflection-in-action. However, the significance of this study reaches beyond a simple analysis of the participant teachers' views on reflection. This study provided an example of 
how to conduct effective analysis of the teacher cognition (or PCK) that lies behind teaching behaviors. In particular, this study unpacked the various types of self-reflection teachers conduct. I hope this study can inspire readers to reflect on their own teaching experiences. I also hope it can aid them to attain deeper levels of self-reflection, which can lead to more effective teaching.

Knowledge about PCK and effective approaches to teacher self-reflection should not be limited to educational researchers but should be mediated by a large number of individuals in various roles. This study can inspire teachers to reflect effectively on their own teaching. Readers of this study may learn of new approaches to resolve or explain their practical difficulties with real-life language teaching practice. This study can also guide teacher educators, educational administrators, and policy makers who want to encourage PCK development. Policies set by educational administrators can help to improve teacher knowledge development (including knowledge related to methods, approaches, strategies, skills, and practices of self-reflection) ${ }^{[36]}$. For example, teachers in government schools can be required to take part in teacher training programs organized by the local bureau of education at least once every year.

PCK is a personal cognitive process and thus is unique to each individual. I hope this study can encourage more people to engage in interpreting their own life and teaching experiences as well as their views on education. The more interpretations people have of PCK and approaches to teacher self-reflection, the clearer our understanding of these topics will become ${ }^{[2]}$.

\section{Research Limitations}

This research needed to be completed within a relatively short period of time, owing to practical considerations. If more time were available, a longitudinal approach could have been adopted as a better choice for this research.

\section{Acknowledgements}

Sincerely appreciate my family for their help in the completion of this article.

\section{References}

[1] Park, S. \& Oliver, J. S. (2008). Revisiting the conceptualization of PCK: PCK as a conceptual tool to understand teachers as professionals. Research in Science Education, 38, 261-284.

[2] Han, G. (2011). Constructing PCK in EFL teachers. Shanghai Foreign Language Education Press.Carter, K. L. (1990). Point charge approximations to a spherical charge distribution: A random walk to high symmetry. Journal of Chemical Education, 67(12), 995-999.

[3] Stern, H. H. (1983). Fundamental concepts of language teaching. Oxford University Press.

[4] Freeman, D. \& Richards, J. C. (1996). Teacher learning in language teaching. Cambridge University Press.

[5] Freeman, D. (1996). Renaming experience/ reconstructing practice: Developing new understanding of teaching. In D. Freeman \& J. C. Richards (Eds.), Teacher learning in language teaching (pp. 221-241). Cambridge University Press.

[6] Richards, J. C. \& Nunan, D. (1990). Second language teacher education. Cambridge University Press.

[7] Richards, J. C. (1998). Beyond training. Cambridge University Press.

[8] Roberts, J. (1998). Language teacher education. Arnold.

[9] Wallace, M. J. (1991). Training foreign language teachers. Cambridge University Press.

[10] Woods, D. (1996). Teacher cognition in language teaching. Cambridge University Press.

[11] Burns, A. (2010). Doing action research in English language teaching: A guide for practitioners. Routledge.

[12] Lin, L. (2004). Chapter 4: The People's Republic of China. In Language policies and language education: The impact in East Asian countries in the next decade ( $2^{\text {nd }}$ ed.). Marshall Cavendish Academic. 
[13] Carter, K. L. (1990). Point charge approximations to a spherical charge distribution: A random walk to high symmetry. Journal of Chemical Education, 67(12), 995-999.

[14] Morine-Dershimer, G. \& Kent, T. (1999). The complex nature and sources of teachers' pedagogical knowledge. In J. Gess-Newsome \& N. Lederman (Eds.), Examining pedagogical content knowledge (pp. 21-50). Kluwer Academic Press.

[15] Fernandez, A. N. (2014, December 9). Crossing the border to kindergarten. Education Week.

[16] Kind, V. (2009). Pedagogical content knowledge in science education: Perspectives and potential for progress. Studies in Science Education, 45(2), 169-204.

[17] Henze, I, Driel, J. H. V., \& Verloop, N. (2007). Science teachers' knowledge about teaching models and modelling in the context of a new syllabus on public understanding of science. Research in Science Education, 37(2), 99-122.

[18] Clandinin, D. Jean, \& Connelly, F. Michael. (1987). Teachers' personal knowledge: What counts as 'personal' in studies of the personal. Curriculum Studies, 19(6), 487-500.

[19] Brown, J. S., Collins, A., \& Duguid, P. (1989). Situated cognition and culture of learning. Educational Researcher, 18(1), 1765-1768.

[20] Nilsson, P. (2008). Teaching for understanding: The complex nature of pedagogical content knowledge in pre - service education. International Journal of Science Education, 30(10), 1281-1299.

[21] Carter, K. L. (1990). Point charge approximations to a spherical charge distribution: A

[22] Eraut, M. (1994). Learning to teach: The Exeter study. Teaching \& Teacher Education, 10(2), $257-263$.

[23] Verloop, N., Driel, J. V., \& Meijer, P. (2001). Teacher knowledge and the knowledge base of teaching. International Journal of Educational Research, 35(5), 441-461.

[24] Reynolds, J. C. (1989). Knowledge base for the beginning teachers. Pergamon Press.

[25] Shulman, L. S. (1987). Knowledge and teaching: Foundations of the new reform. Harvard Educational Review, 57, 1-22.

[26] Nilsson, P. (2008). Teaching for understanding: The complex nature of pedagogical content knowledge in pre - service education. International Journal of Science Education, 30(10), 1281-1299.

[27] Schön, D. A. (1983). The reflective practitioner: How professionals think in action. Temple.

[28] Cruickshank, D. (1985). Profile of an effective teacher. Educational Horizons, 64(2), 80-86.

[29] Grimmet, P., Makinnon, A., Erickson, G., \& Riecken, T. (1990). Reflective practice in teacher education. In R. T. Clift, W. R. Houston, \& M. Pugach (Eds.), Encouraging reflective practice: An analysis of issues and programs. Teachers College Press.

[30] Mayring, P. (2000). Pensionierung als krise oder glücksgewinn? Ergebnisse aus einer quantitativ-qualitativen längsschnittuntersuchung. Zeitschrift Für Gerontologie Und Geriatrie, 33(2), 124-133.

[31] Glaser, B. G., \& Strauss, A. L. (1967). The discovery of grounded theory: Strategies for qualitative research. Aldine Transaction.

[32] Thornberg, R, \& Charmaz, K. (2012). Grounded theory. In S. D. Lapan, M. Quartaroli, \& F. Reimer (Eds.), Qualitative research: An introduction to methods and designs (pp. 41-67). Jossey-Bass.

[33] Merriam, S. B. (1998). Qualitative research and case study applications in education. Jossey-Bass.

[34] Stake, R. E. (2006). Multiple case study analysis. Guilford.

[35] Yin, R. K. (2003). Case study research: Design and methods (3rd ed.). Sage. 